NBER WORKING PAPER SERIES

\title{
INTER-ASSET DIFFERENCES IN EFFECTIVE ESTATE TAX BURDENS
}

\author{
James Poterba \\ Scott Weisbenner \\ Working Paper 9456 \\ http://www.nber.org/papers/w9456
NATIONAL BUREAU OF ECONOMIC RESEARCH
1050 Massachusetts Avenue
Cambridge, MA 02138
January 2003

We are grateful to Barry Johnson and Lisa Schreiber of the Statistics of Income Division at the Internal Revenue Service for providing us with unpublished tabulations, and to Jane Gravelle, Joel Slemrod, and Michael Udell for helpful discussions. Poterba thanks the National Science Foundation, and Weisbenner the College Research Board at the University of Illinois at Urbana-Champaign, for research support. The views expressed herein are those of the authors and not necessarily those of the National Bureau of Economic Research.

(C)2003 by James Poterba and Scott Weisbenner. All rights reserved. Short sections of text not to exceed two paragraphs, may be quoted without explicit permission provided that full credit including notice, is given to the source. 
Inter-Asset Differences in Effective Estste Tax Burdens

James Poterba and Scott Weisbenner

NBER Working Paper No. 9456

January 2003

JEL No. H2

\section{$\underline{\text { ABSTRACT }}$}

This paper explores the effect of discretion in estate valuation techniques on the effective estate tax burden on different asset classes. For some assets, such as liquid securities, there is relatively little discretion in valuation. For other assets, such as partial interests in closely-held businesses, family limited partnerships, and real assets or collectibles that are traded in thin markets, estate valuations may be more difficult to establish. Estate tax filers may therefore be able to select valuations that reduce the reported value of the estate assets, and therefore the effective estate tax burden. In 1998, estates that invoked the doctrine of "minority discounts" in valuing non-controlling interests in limited partnerships claimed an average discount of 36 percent for these assets, relative to their estimated market value. More than half of all limited partnership assets reported on estate tax returns were valued using this doctrine. This suggests that for a given statutory estate tax rate, the effective estate tax burden may be greater on assets that are easily valued than on difficult-tovalue assets. A comparison of the mix of assets reported on estate tax returns, and the mix the estate tax returns would be predicted to hold, given data from the Survey of Consumer Finances, is consistent with lower relative valuations for difficult-to-value assets.

James M. Poterba

Department of Economics, E52-350

MIT, 50 Memorial Drive

Cambridge, MA 02143-1347

and NBER

poterba@mit.edu
Scott J. Weisbenner

Department of Finance

University of Illinois

304c David Kinley Hall

Urbana, IL 61801

and NBER

weisbenn@uiuc.edu 
Research on the income tax has long recognized differences in the tax treatment of capital income from different assets, and considered the efficiency and distributional effects of such differences.

Research on the estate tax, in contrast, has typically viewed the tax as applying at an equal effective rate to all types of assets. While special estate tax provisions for family businesses and for farms, reduce the effective estate tax burden for these asset classes, the statutory estate tax rate is the same for all other assets. In practice, however, different assets within an estate may be subject to different effective estate tax burdens. Such differences are potentially important when assessing the investment and portfolio allocation effects that are associated with the estate tax.

Difficult-to-value assets, such as physical assets that are traded in thin markets and partial interests in businesses whose market value may be reduced by the presence of corporate control concerns, in many cases face effective estate tax rates that are lower than the statutory rate. The estate tax may therefore provide incentives for households to accumulate wealth in these forms. Estate tax reduction, in turn, will have a smaller impact on investment in these assets than on investment in other asset classes.

In this brief paper, we explain how discretionary valuation and minority discounts can reduce the effective estate tax rates on some asset classes. We then present some evidence on the potential significance of these factors by comparing the composition of assets that are reported on estate tax returns with the composition of assets held by "potential decedents" in a household survey, the Survey of Consumer Finances. Our empirical findings suggest that real estate and business assets account for a larger share of household net worth for survey respondents than for decedents. This is consistent with a lower effective estate tax burden on these assets than on more liquid assets, such as stocks and bonds.

\section{Valuation Problems: Appraisal Shopping and Minority Discounts}

The estate tax is levied on the reported value of the decedent's estate. In some situations, for example when the decedent's assets consist only of financial assets with readily-available market values, the computation of this value is straightforward. When the assets in the estate are difficult to value, however, the individuals filing the estate tax return may have some discretion in the values that they 
report. Consider the problem of valuing a unique piece of art, or a residence that has specialized attributes such as an appealing location. Different appraisers might value the estate asset differently, and in such a situation, the estate tax filers will attempt to choose a low but defensible valuation. David Geltner (1998) estimates that the standard deviation for estimates of appraisals of a given commercial real estate properties is between five and ten percent. Barry Johnson, Jacob Mikow, and Martha Britton Eller (2001) provide examples of much wider differences in the valuation of assets reported on estate tax returns and offered by government witnesses in legal cases. Third party reviewers may have incentives to select a low valuation, since to do otherwise might expose them to potential suits from the beneficiaries of the estate. The IRS can challenge an estate valuation - but the burden of proof in showing that the estate chose an unreasonable valuation is high, discouraging challenge in all but the most flagrant cases. To the extent that estate tax returns are prepared using "low-end" valuations of difficult to value assets, the effective estate tax burden on these assets is reduced.

The difficulties associated with valuation are compounded when the assets in question are minority shares in closely-held businesses. Consider an enterprise that generates $\$ 1$ million each year, in perpetuity, net of business taxes, and assume that the risk-adjusted discount rate that applies to this business' cash flows is ten percent per year. Standard valuation methods would value this business at $\$ 10$ million. However, if a decedent owned only one third of the business, what is the value of this claim? The simplest answer - \$3.33 million - does not capture the fact that a one-third owner of the business may not be able to prevent majority owners from reducing the value of the enterprise in order to recognize private gains. This very real concern with the governance of closely-held businesses has given rise to the "minority discount" doctrine in estate valuation. A key question in this regard, however, is how large a discount to apply to the assets. Experts disagree on the potential costs of expropriation associated with minority ownership, and estate tax filers can argue for reduced valuation.

During the 1990s, the use of minority discounts became more common, and the extent of discounting also increased. Richard Schmalbeck (2001) explains that the federal tax court held that even in situations in which the totality of a closely held business was included in the estate, but was distributed 
to different family members so that each received a minority stake, it became acceptable to apply a minority discount to the total value of the business. The court accepted the argument that the value of the entire entity should be reduced by the lower valuation that was associated with each of the beneficiaries. Because minority discounts can be applied to family limited partnerships, there has been a growing tendency to create such ownership structures and to hold a variety of assets within such structures. Family limited partnerships can even be used to hold liquid securities, which are easily valued, and in some cases to claim a minority discount even for these assets. State-of-the-art estate planning has come to rely increasingly on the creation of family limited partnerships.

The extent to which different types of assets can be valued net of a minority discount creates potential inter-asset differences in effective estate tax rates. In 1998, 3755 taxable estate tax returns claimed minority discounts. Table 1 shows the number of returns claiming these discounts on various types of assets, and the average percentage discount on these assets. The average discount was 25.3 percent. For some asset classes, however, notably ownership interests in limited partnerships and shares in closely-held businesses, the discount was larger. It was more than one third for limited partnerships. The fraction of estate tax returns claiming minority discounts also varies substantially across different asset categories.

Table 2 presents information on the fraction of estate tax returns with various types of assets that claim a minority discount. It also shows the fraction of assets in each category that are valued using minority discounts. Nearly two thirds of the closely-held stock reported on estate tax returns, and more than half of the assets in limited partnerships, claim such discounts. By comparison, less than three percent of the publicly traded stock is affected by minority discounts. It is possible that some marketable financial assets, such as publicly traded stock, are held in limited partnerships. Such assets would effectively receive a minority discount. Existing data do not enable us to identify the assets inside limited partnerships.

The data in Tables 1 and 2 can be combined to assess the impact of minority discounts on estate tax liability. We view the estate tax liability for a given decedent as TAX $=\tau\left(\sum_{\mathrm{i}} \lambda_{\mathrm{i}} * \mathrm{~V}_{\mathrm{i}}\right)$ where $\tau()$ is the 
statutory estate tax function, $\lambda_{\mathrm{i}}$ denotes the ratio of the taxable value and the actual value of assets in category $i$, and $V_{i}$ denotes the market value of assets in category $i$. The results in the foregoing tables suggest that roughly 19 percent of limited partnership assets $(.363 * .528), 20$ percent of closely-held business assets $(.298 * .656)$, and 16 percent of farm assets $(.20 * .79)$, avoid estate taxation because they are excluded from the estate tax base via minority discounting. For most other asset classes, the percentage of total asset value escaping taxation because of minority discounting is less than one percent. Thus for several asset classes $\lambda_{\mathrm{i}}$ is near .80 , while for many others it is close to 1.0 .

Table 3 presents information on the use of minority discounts by estates of different sizes. For each asset type, the table distinguishes assets held in estates with a gross value of more than $\$ 2.5$ million from assets held in estates that were smaller than this threshold. The results indicate that minority discounts are used more frequently by larger estates. For example, 50 percent of the closely-held stock in gross estates valued at less than $\$ 2.5$ million received a minority discount, compared with 67 percent of such stock in estates valued at more than $\$ 2.5$ million.

\section{Disaggregate Evidence of Differential Valuation for Different Asset Classes}

It is difficult to gauge the substantive importance of various estate tax minimization strategies. There is no historical information, for example, on the use of minority discounts. Moreover, as George Cooper (1979) emphasized, there are many ways for potential decedents to reduce their estate tax liability, and changes in the use of one strategy may simply reflect inter-strategy substitution rather than changes in overall estate tax avoidance.

To provide some evidence on inter-asset differences in effective estate tax rates, which might be due to the use of minority discounts, we compare the composition of assets reported on estate tax returns with the composition of assets in the portfolios of individuals who are similar to the decedents. If a given asset category is accounts for a smaller share of estate tax wealth than of wealth for wealthy individuals who might die in near future, we interpret this as evidence of reduced valuation on estate tax returns. 
We follow a procedure developed by Edward Wolff (1996), Poterba (2000), and Poterba and Weisbenner (2001). We compare estate tax data with data from the Survey of Consumer Finances (SCF). The SCF is a stratified random sample of households in the United States. It is conducted every three years, with the most recent publicly-available surveys in 1998, 1995, 1992, and 1989. The survey includes both a random sample of households, as well as a sample of high-income households, drawn from areas with a high concentration of high-income tax returns. A sampling weight is assigned to each household in the survey. The survey can be used to generate population aggregates by summing the product of household attributes and sampling weights. For example, if $\mathrm{W}_{\mathrm{h}}$ is the total net worth reported by household $\mathrm{h}$, and $\mathrm{w}_{\mathrm{h}}$ is the sampling weight for household $\mathrm{h}$, we can estimate total household net worth as $\Sigma_{\mathrm{h}} \mathrm{W}_{\mathrm{h}} * \mathrm{~W}_{\mathrm{h}}$.

In married couples, the first spouse to die can take advantage of the unlimited marital bequest, but need not do so. This makes it more difficult to assess the prospective estate tax liability of married couples than of single individuals. To study differences between the portfolio composition of SCF households and that of decedents, we restrict our analysis to single persons in the SCF. We define $\mathrm{q}_{\mathrm{h}}$ as the probability of death during a one-year period, computed using the respondent's age and the Annuitant Mortality Table. We then compute the expected value of the total estate-taxable wealth (EW) for the coming year as $\mathrm{EW}=\sum \mathrm{q}_{\mathrm{h}} * \mathrm{~W}_{\mathrm{h}} * \mathrm{I}_{\mathrm{W}>600 \mathrm{~K}, \mathrm{~h}} * \mathrm{~W}_{\mathrm{h}}$. The indicator variable $\mathrm{I}_{\mathrm{W}>600 \mathrm{~K}, \mathrm{~h}}$ is equal to unity when the respondent's net worth is greater than $\$ 600,000$ (\$625,000 in 1998). It indicates that the respondent's death would trigger an estate tax filing.

The expected estate-taxable wealth generated by this algorithm underestimates the amount of wealth actually reported on estate tax returns. In 1998, EW for single person households in the SCF was $\$ 66.5$ billion. The gross estates for tax purposes of single decedents in 1998 , on whose behalf estate tax returns were filed, totaled $\$ 103.9$ billion, making EW only 64 percent as large. The underestimates in other years range from 8 percent in 1995 to 31 percent in 1992. 
There are several potential explanations for this understatement. One is that the SCF excludes the very wealthiest households, a group roughly corresponding to the Forbes 400 . The wealth of this group plays a non-trivial and highly volatile part in generating estate tax revenues. By excluding this group, the

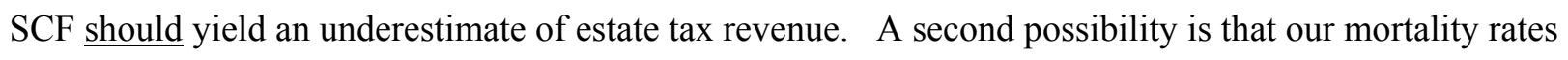
are too low. We use annuitant mortality rates, which are lower than those for the general population, and which generally offer a reasonable guide to the mortality rates for the high-net worth population. It is possible, however, that they understate the actual mortality experience for single high-net worth individuals. Mortality rates at older ages are higher for single individuals than for those who are married.

Table 4 presents compares the composition of assets in estate tax filings with those in the SCF. If $\mathrm{W}_{\mathrm{h}, \mathrm{j}}$ denotes household h's wealth holdings in asset category $\mathrm{j}$, our estimate of the share of taxable estates from the SCF that will be accounted for by asset category $\mathrm{j}$ is:

$$
\text { Asset Share } \mathrm{j}=\left(\sum \mathrm{q}_{\mathrm{h}}{ }^{*} \mathrm{w}_{\mathrm{h}} * \mathrm{I}_{\mathrm{W}>600 \mathrm{~K}, \mathrm{~h}} * \mathrm{~W}_{\mathrm{h}, \mathrm{j}}\right) /\left(\sum \mathrm{q}_{\mathrm{h}}{ }^{*} \mathrm{w}_{\mathrm{h}} * \mathrm{I}_{\mathrm{W}>600 \mathrm{~K}, \mathrm{~h}} * \mathrm{~W}_{\mathrm{h}}\right) \text {. }
$$

The first panel presents our results for all estates, while the lower sub-panels focus on subsets of estates.

For all taxable estates, we find that in 1998, 37.3 percent of total estate value is accounted for by common stock. By comparison, 5.7 percent is accounted for by assets in closely-held businesses. Our expected asset shares based on the SCF data, however, are 28.1 percent for stocks and 14.0 percent for business equity. Cash, like stock, is more important in the estate tax filings than in the SCF. It accounts for 36.9 percent of the value of estates, compared with an expected value of 30.2 percent in the SCF. Both owner occupied housing and other real estate assets, like closely held businesses, account for a smaller share of the assets on estate tax filings than the SCF-based expectation would suggest.

The broad patterns that we find are stable across years, although the disparities between the estate tax filings and the SCF-based estimates appear to have diminished over time. In 1989, for example, the share of stocks in estate tax wealth was 2.8 times the expected share in the SCF. This share ratio declined to 1.3 by 1998 . The actual and the predicted shares of stock in estate values trend up over the 1989-1998 period, reflecting the rise in equity values during this period. The share of real estate assets, both owneroccupied homes and other real estate, declines over this period. 
The entries in the two lower panels of Table 4 show that the relationships that we observe for all estates are more pronounced for the largest estates. The middle panel presents tabulations for estates valued at between $\$ 1$ and $\$ 5$ million, while the lower panel shows estates valued at more than $\$ 20$ million. There are substantial differences between these two groups, both in the estate tax return asset mix and in the differences between this and the estimated asset mix from the SCF.

The share of assets accounted for by businesses is much higher for very large estates than for more modest ones. While businesses account for 3.2 percent of the assets in estates valued at between $\$ 1$ and $\$ 5$ million, they account for 17.6 percent of the assets in estates of $\$ 20$ million and more. The difference between the value in estate tax filings, and the value in our SCF-based estimates, is also larger for the largest estates. In 1998, the share of business assets in estate tax filings was roughly one third of the SCF-based estimate for the largest estates, while it was one half for the estates valued at between $\$ 1$ and \$5 million. Estates worth more than $\$ 20$ million also show a higher share of stock than smaller estates, and a much lower share of owner-occupied housing. The relationship between the SCF-based asset shares, and the estate tax return shares, varies more from year to year for the largest estates than for smaller ones, presumably due to the small number of large estates in each year. The difference between the SCF-based asset share for businesses, and the estate tax share for these assets, is larger in the late 1990s than a decade earlier, possibly because of the increased use of minority discounts.

\section{Interpretation}

Our results from the SCF - estate tax filing comparisons are consistent with what we would predict if minority discounts and other strategies for reduced valuation were used more frequently for non-marketable assets than for more liquid components of wealth. Our findings could, however, also be due to other factors. One implicit assumption in our analysis is that decedents do not transform their portfolios in the months or years before they die, as they might if they fell into poor health and expected that they would die sometime soon. Such transactions could explain differences between the observed composition of estates and the composition of the portfolios of those who were still alive. It is also possible that tax distortions related to the realization-based taxation of capital gains contribute to 
differences between the portfolios we see in estate tax filings, and other portfolios. If taxpayers who expect to die before too long do not trade assets with large embedded capital gains, this could lead to differences between the portfolios of decedents and the portfolios of those who remain alive.

The results suggest that eliminating the estate tax may have a larger impact on the incentive to invest in marketable assets that are easy to value than on the investment incentives for more specialized assets or closely-held businesses. Further work should consider the inter-asset distortions that may be associated with the estate tax. In particular, we are not aware of any research on the efficiency costs of changes in the ownership structure of assets, such as the creation of family limited partnerships or related entities. If such entities create governance conflicts, then it is possible that estate tax avoidance through this channel replaces explicit estate tax payments with other implicit costs borne by estate beneficiaries. 


\section{$\underline{\text { References }}$}

Cooper, George. A Voluntary Tax? New Perspectives on Sophisticated Estate Tax Avoidance. Washington: Brookings Institution, 1979.

Geltner, David. "How Accurate is the NCREIF Index as a Benchmark, and Who Cares?," Real Estate Finance, 14 (Winter 1998).

Johnson, Barry W., Jacob M. Mikow, and Martha Britton Eller. "Elements of Federal Estate Taxation," in William Gale, James R. Hines, Jr., and Joel Slemrod, eds., Rethinking Estate and Gift Taxation. Washington: Brookings Institution, 2001, pp. 65-107.

Johnson, Barry W., and Jacob M. Mikow. “Federal Estate Tax Returns, 1998-2000.” Statistics of Income Bulletin 21 (Spring 2002), pp. 133-186.

Poterba, James M. “The Estate Tax and After-Tax Investment Returns,” in J. Slemrod, ed., Does Atlas Shrug? The Economic Consequences of Taxing the Rich. Cambridge: Harvard University Press, pp. 333-353.

Poterba, James M., and Scott J. Weisbenner. “The Distributional Burden of Taxing Estates and Unrealized Capital Gains at Death,” in William Gale, James R. Hines, Jr., and Joel Slemrod, eds., Rethinking Estate and Gift Taxation. Washington: Brookings Institution, 2001, pp. 422-449.

Schmalbeck, Richard. “Avoiding Federal Wealth Transfer Taxes,” in William Gale, James R. Hines, Jr., and Joel Slemrod, eds., Rethinking Estate and Gift Taxation. Washington: Brookings Institution, 2001, pp. 113-158.

Wolff, Edward. “Commentary.” Tax Law Review 51 (Spring 1996), pp. 517-522. 
Table 1: Taxable 1998 Estate Tax Returns Claiming Minority Discounts, by Asset Category

\begin{tabular}{|l|l|l|l|}
\hline Asset Type & Number of Returns & $\begin{array}{l}\text { Total Discount } \\
(\$ \text { million })\end{array}$ & $\begin{array}{l}\text { Average Percentage } \\
\text { Discount }\end{array}$ \\
\hline Limited Partnerships & 673 & 336.5 & 36.3 \\
\hline Closely Held Stock & 1252 & 1289.3 & 29.8 \\
\hline Other Non-Corporate & 281 & 70.1 & 23.5 \\
\hline Farm Assets & 702 & 66.6 & 20.0 \\
\hline Publicly Traded Stock & 100 & 109.1 & 10.0 \\
\hline Personal Residence & 310 & 12.9 & 18.8 \\
\hline Real Estate & 1348 & 208.5 & 18.2 \\
\hline Mortgages and Notes & 95 & 7.8 & 13.9 \\
\hline Other & 97 & 20.8 & 14.1 \\
\hline All Assets & 3755 & 2121.7 & 25.3 \\
\hline
\end{tabular}

Source: Johnson, Mikow, and Eller (2001), page 99, and unpublished data provided by Barry Johnson. 
Table 2: Taxable 1998 Estate Tax Returns Claiming Minority Discounts, by Asset Category

\begin{tabular}{|l|l|l|}
\hline Asset Type & $\begin{array}{l}\text { Percent of Returns with asset } \\
\text { that take discount on asset }\end{array}$ & $\begin{array}{l}\text { Percent of total asset value } \\
\text { subject to discount }\end{array}$ \\
\hline Limited Partnerships & 12.3 & 52.8 \\
\hline Closely Held Stock & 30.4 & 65.6 \\
\hline Other Non-Corporate & 10.1 & 41.7 \\
\hline Farm Assets & 24.2 & 79.0 \\
\hline Publicly Traded Stock & 0.3 & 2.8 \\
\hline Personal Residence & 1.2 & 1.1 \\
\hline Real Estate & 5.7 & 13.6 \\
\hline
\end{tabular}

Source: Authors' calculations based on Johnson, Mikow, and Eller (2001), page 99, and unpublished data provided by Barry Johnson.

Table 3: Taxable 1998 Estate Tax Returns Claiming Minority Discounts, by Asset Category and Gross Estate Value

\begin{tabular}{|l|l|l|l|l|}
\hline \multirow{2}{*}{ Asset Type } & \multicolumn{2}{|l|}{$\begin{array}{l}\text { Percent of Returns with asset } \\
\text { that take discount on asset }\end{array}$} & $\begin{array}{l}\text { Percent of total asset value } \\
\text { subject to discount }\end{array}$ \\
\cline { 2 - 5 } & $\begin{array}{l}\text { Gross Estate } \\
<\$ 2.5 \text { million }\end{array}$ & $\begin{array}{l}\text { Gross Estate } \\
\mathbf{2} \$ 2.5 \text { million }\end{array}$ & $\begin{array}{l}\text { Gross Estate } \\
<\$ 2.5 \text { million }\end{array}$ & $\begin{array}{l}\text { Gross Estate } \\
\mathbf{\$} 2.5 \text { million }\end{array}$ \\
\hline Limited Partnerships & 10.5 & 15.6 & 54.3 & 52.5 \\
\hline Closely Held Stock & 24.2 & 38.2 & 49.9 & 67.2 \\
\hline Other Non-Corporate & 8.3 & 13.2 & 31.7 & 43.5 \\
\hline Farm Assets & 22.5 & 32.4 & 85.8 & 71.9 \\
\hline Publicly Traded Stock & 0.2 & 0.7 & 0.2 & 4.3 \\
\hline Personal Residence & 1.0 & 1.7 & 0.8 & 1.5 \\
\hline Real Estate & 4.6 & 10.3 & 8.8 & 19.1 \\
\hline
\end{tabular}

Source: Authors' calculations based on unpublished data provided by Barry Johnson. 
Table 4: Composition of Gross Estates of Single Decedents: Actual Values from SOI and Estimates (in parentheses) From Four Surveys of Consumer Finances

\begin{tabular}{|c|c|c|c|c|}
\hline & 1998 & 1995 & 1992 & 1989 \\
\hline \multicolumn{5}{|c|}{ All Estates Valued at More Than $\$ 600,000(\$ 625,000$ in 1998$)$} \\
\hline Stocks & $\begin{array}{l}37.3 \% \\
(28.1)\end{array}$ & $\begin{array}{l}29.1 \% \\
(25.1)\end{array}$ & $\begin{array}{c}27.4 \% \\
(16.8)\end{array}$ & $\begin{array}{c}26.6 \% \\
(9.4)\end{array}$ \\
\hline Cash/Bonds & $\begin{array}{c}36.9 \\
(30.2) \\
\end{array}$ & $\begin{array}{c}42.3 \\
(30.6) \\
\end{array}$ & $\begin{array}{c}41.9 \\
(30.1)\end{array}$ & $\begin{array}{c}37.1 \\
(18.5) \\
\end{array}$ \\
\hline Business & $\begin{array}{c}5.7 \\
(14.0)\end{array}$ & $\begin{array}{c}6.1 \\
(10.8)\end{array}$ & $\begin{array}{c}7.0 \\
(11.5)\end{array}$ & $\begin{array}{c}8.3 \\
(23.7)\end{array}$ \\
\hline House & $\begin{array}{c}6.8 \\
(12.1)\end{array}$ & $\begin{array}{c}6.6 \\
(10.7)\end{array}$ & $\begin{array}{c}7.0 \\
(13.8)\end{array}$ & $\begin{array}{c}8.8 \\
(14.5)\end{array}$ \\
\hline Real Estate & $\begin{array}{c}10.8 \\
(14.1)\end{array}$ & $\begin{array}{c}12.0 \\
(12.6)\end{array}$ & $\begin{array}{c}13.2 \\
(21.9)\end{array}$ & $\begin{array}{c}14.1 \\
(30.6)\end{array}$ \\
\hline Other & $\begin{array}{c}2.5 \\
(1.5)\end{array}$ & $\begin{array}{c}4.0 \\
(10.2)\end{array}$ & $\begin{array}{c}3.6 \\
(5.9)\end{array}$ & $\begin{array}{c}5.1 \\
(3.3)\end{array}$ \\
\hline \multicolumn{5}{|c|}{ Estates Valued at $\$ 1-5$ Million } \\
\hline Stocks & $\begin{array}{c}35.5 \\
(28.2)\end{array}$ & $\begin{array}{c}28.8 \\
(29.9)\end{array}$ & $\begin{array}{c}27.4 \\
(16.2)\end{array}$ & $\begin{array}{l}27.7 \\
(4.6)\end{array}$ \\
\hline Cash/Bonds & $\begin{array}{c}40.1 \\
(31.9)\end{array}$ & $\begin{array}{c}43.8 \\
(29.9)\end{array}$ & $\begin{array}{c}43.9 \\
(29.1)\end{array}$ & $\begin{array}{c}38.9 \\
(15.2)\end{array}$ \\
\hline Business & $\begin{array}{c}3.2 \\
(6.4)\end{array}$ & $\begin{array}{c}3.6 \\
(6.8)\end{array}$ & $\begin{array}{c}3.9 \\
(7.7)\end{array}$ & $\begin{array}{c}5.4 \\
(30.1)\end{array}$ \\
\hline House & $\begin{array}{c}7.7 \\
(15.5)\end{array}$ & $\begin{array}{c}7.3 \\
(14.0)\end{array}$ & $\begin{array}{c}7.4 \\
(15.9)\end{array}$ & $\begin{array}{c}9.5 \\
(11.5)\end{array}$ \\
\hline Real Estate & $\begin{array}{c}11.9 \\
(16.5)\end{array}$ & $\begin{array}{r}12.9 \\
(8.0) \\
\end{array}$ & $\begin{array}{c}14.4 \\
(24.4)\end{array}$ & $\begin{array}{c}14.9 \\
(36.4) \\
\end{array}$ \\
\hline Other & $\begin{array}{c}1.8 \\
(1.5)\end{array}$ & $\begin{array}{c}3.7 \\
(11.4)\end{array}$ & $\begin{array}{c}3.1 \\
(6.7) \\
\end{array}$ & $\begin{array}{c}3.7 \\
(2.2) \\
\end{array}$ \\
\hline \multicolumn{5}{|c|}{ Estates Valued at More Than \$20 Million } \\
\hline Stocks & $\begin{array}{l}48.4 \% \\
(22.6)\end{array}$ & $\begin{array}{c}41.6 \% \\
(36.0)\end{array}$ & $\begin{array}{l}31.8 \% \\
(26.1)\end{array}$ & $\begin{array}{c}28.1 \\
(11.5)\end{array}$ \\
\hline Cash/Bonds & $\begin{array}{c}20.8 \\
(11.7)\end{array}$ & $\begin{array}{c}26.7 \\
(36.6)\end{array}$ & $\begin{array}{c}25.7 \\
(14.8)\end{array}$ & $\begin{array}{c}22.5 \\
(28.3) \\
\end{array}$ \\
\hline Business & $\begin{array}{c}17.6 \\
(56.7)\end{array}$ & $\begin{array}{c}17.8 \\
(11.1)\end{array}$ & $\begin{array}{c}26.1 \\
(39.0)\end{array}$ & $\begin{array}{c}26.4 \\
(39.7)\end{array}$ \\
\hline House & $\begin{array}{c}1.5 \\
(2.4) \\
\end{array}$ & $\begin{array}{c}1.1 \\
(1.3)\end{array}$ & $\begin{array}{c}1.5 \\
(1.3) \\
\end{array}$ & $\begin{array}{c}1.5 \\
(4.1) \\
\end{array}$ \\
\hline Real Estate & $\begin{array}{c}5.8 \\
(5.9)\end{array}$ & $\begin{array}{c}5.5 \\
(7.0)\end{array}$ & $\begin{array}{c}8.4 \\
(12.4)\end{array}$ & $\begin{array}{c}7.4 \\
(8.9)\end{array}$ \\
\hline Other & $\begin{array}{c}6.0 \\
(0.6)\end{array}$ & $\begin{array}{c}7.2 \\
(7.9)\end{array}$ & $\begin{array}{c}6.5 \\
(6.4)\end{array}$ & $\begin{array}{l}14.2 \\
(7.6)\end{array}$ \\
\hline
\end{tabular}

Source: Entries from Statistics of Income are based on unpublished tabulations provided by Barry Johnson and Lisa Schreiber. SCF calculations are based on authors' estimates, as described in the text. 